\title{
Land Distribution and Economic Development: Small Scale Agriculture in Developing Countries
}

\author{
Harriet Kasidi Mugera \\ University of Trento, Trento, Italy
}

\begin{abstract}
Small scale farmers constitute about half of world's hungry people and include three quarters of Africa's malnourished children. The appropriate identification and characterization of this population and the constraints it faces are essential for the design and the successful implementation of safety nets and to properly target their needs and effectively include them in agricultural development strategies. This paper aims at exploring the characteristics, limitations, and potential for agricultural development of small scale farmers in developing countries. It calculates four land cultivated thresholds which are then used as a measure to classify households that were surveyed in four developing countries. It empirically estimates the magnitudes of the smallholders, their characteristics, as well as their poverty status using the four thresholds. This analysis provides empirical evidence that small scale farmers still prevail in terms of population distribution in rural area settings in developing countries. Small scale farmers heavily rely on farm income as their form of livelihood and heavily contribute to the rural income. It also finds that land is unequally distributed among small and large scale farmers in the rural households. Small scale farmers also have the highest poverty rates in these rural settings.
\end{abstract}

Keywords: agriculture, small scale farming, land distribution, developing countries, poverty, inequality

\section{Introduction}

It has been estimated that about $70 \%$ of world's poor are concentrated in rural areas where two out of three billion rural people reside in about 450 million small farms. Over the last decade, changes in the patters of agricultural production and trade have affected the traditional agricultural paradigm in terms of economic, social, or even political power (World Bank, 2008; Hazell, Poulton, Wiggins, \& Dorward, 2007).

The role of the smallholders has not been fully addressed in association with recent challenges in the global economy and with respect to the changing role of agriculture along development transition. There is a need for appropriate characterization of smallholders and the identification of the constraints that they face. This is a crucial step for the design and the successful implementation of safety nets. While the estimates regarding the magnitude of small land holders and their poverty status are impressive, the roughness and lack of further information on the characteristics and the constraints they face make it necessary for more researches in order to be able to better target their needs and effectively include them in agricultural development strategies.

Harriet Kasidi Mugera, Ph.D., researcher, Department of Economics and Management, University of Trento, Via Inama, Trento (TN), Italy.

Correspondence concerning this article should be addressed to Harriet Kasidi Mugera, Department of Economics and Management, University of Trento, Via Inama, I-38122 Trento (TN), Italy. E-mail: harriet.mugera@unitn.it. 
The success of the Green Revolution has influenced the evolution of policies with policy makers advocating for a more active role for agriculture in the overall economic development. In Asia, adoption of technological advances even among the smallholders implied that agriculture could play a leading role in economic growth. The role of small scale agriculture has different economic and policy implications.

Smallholders can have significant advantages especially in terms of efficiency in the production of staple foods. There is rich literature providing evidence on how use of family labor in the small farms increases efficiency (Fan \& Chan-Kang, 2005). The results from greater intensity in the use of inputs, especially of family labor, have positive consequences for food security. In general, the use of family labor offers higher flexibility less possible in larger farm settings as these depend on waged workers. Smallholder production is also more suitable for labor-intensive products (such as vegetables) that require transplanting and multiple harvests by hand and for other products that require attention to detail. Moreover, smallholders may positively contribute to the rural economy as a whole by encouraging the expenditure patterns in these local settings. Consequently, small scale agriculture provides a livelihood foundation to the rural economy.

The recent food price spikes have strengthened the emphasis on smallholders as food producers and how smallholders could easily become vulnerable to price shocks. In 2009, at both the l'Aquila G8 Meeting and the Food and Agricultural Organization (FAO) World Summit on Food Security, world leaders underlined the importance of small farmers in achieving global food security and called for a new global partnership towards improving their productivity and incomes. This is particularly relevant in Africa where poor infrastructure and rain-fed agriculture render the situation of small scale farmers more challenging. This issue has therefore posed the question - whether small scale farming should persist. Evidence from Brazil advocates for policies that facilitate the transition of small scale to large scale farming as it managed to commercialize its agricultural sector by implementing new technologies, finance, and integration into the international supply chains. There are success experiences, such as Thailand where smallholders did manage to commercialize the agricultural sector. This mixed evidence suggests that both small and large scale agriculture can lead to agricultural and economic development. It, however, poses the challenge on the persistence of small scale agriculture.

The objective of this paper is to explore the characteristics, limitations, and the potential for agricultural development of small scale farmers in the developing countries and particularly in Africa. It will develop indicators based on the rural income generating activities (RIGA) household survey data.

The paper is structured as follows: agricultural economic theory; defining small-holder farmers; challenges facing small-scale agriculture; methodology and data; results; and concluding remarks.

\section{Agricultural Economic Theory}

The standard economic theory defined development as the economic growth process which occurs due to an appropriate reallocation of production factors from the low productivity rural (agricultural) sector to the urban (industrialized) sector. In this setting, the agricultural sector supplied the urban areas with food thus releasing savings and labor which then enhanced industrialization. This theory has faced criticisms, due to distortions stemming from the impact of high food demand and prices as wages in the urban sector along with the living standards improve.

The success of Green Revolution modified classical theory and policy guidelines, assuming a more active role for agriculture in overall development. The new models known as the innovation models included new ways of thinking. In particular, technological advances indicated that agriculture could contribute to overall 
growth, through productivity increases, thus overcoming resource constraints. Technological innovations are often dependent on natural endowments and market forces for inputs and outputs being endogenous to the country's agricultural transformation process. Forward and backward linkages, not only in agriculture, but also in demand and supply, highlight the crucial role of agriculture in development.

These linkage effects are identified by investing in the industrial sector and the potential impact this sector has to the rural economy. Subsequently, rural production and consumption linkages can be determined as a result of the utilization of agricultural output as input to the industrial sector as well as from the demand for inputs generated from agriculture respectively. In this process, effects from trade depend on the elasticity of substitution between domestic and foreign commodities as well as the existence of non-tradable commodities. Nevertheless, serious constraints in rural areas, in terms of imperfect or missing markets, high transaction costs and poor infrastructure, limit the exploitation of these linkages, hindering agricultural transformation and development transition. Setting-up of development policy objectives that aim at overcoming these constraints as well as promoting industrialization is essential.

Within the context emerging in the aftermath of the Green Revolution success, small scale agriculture is seen as the backbone of agricultural transformation. Its role is multidimensional, starting primarily from its efficiency advantage, relative to large scale farming and its contribution to the rural economy and national food security through favorable expenditure patterns in the local economy as well as through the concentration of agricultural produce to staple food items, respectively. As a result of these functions, small scale agriculture consists for itself and provides the rural economy with a livelihood platform which is able to accommodate poverty reduction and food security along with welfare improvement objectives.

Beyond the advantages offered by small scale farmers, stabilization of social and economic structures is added as agriculture and small scale farming helps to overcome the impact of food crises. Moreover, the decision process and the management of small scale farms within its most frequent organizational form, the family farm, are supposed to promote learning and innovation.

\section{Defining Small Holder Farmers}

There is no unique definition of smallholder farmers. Different indicators have been identified in order to define small scale farmers. Land ownership is one of them. Limited access to land is the common identification feature, when the term smallholder is mentioned in the literature. The limit most frequently takes the form of a threshold that is usually selected in an ad hoc basis (two hectares, mean or median land size), for example, households with less than a threshold land size of two hectares may be characterized as smallholders. However, across countries, the distribution of farm sizes depends on many other factors, such as agro-ecological and demographic conditions and economic and technological factors. Chamberlin (2008), using survey data from Ghana, employed farm size as the classification variable and defined smallholders as farmers with operated farm size smaller than 10 hectares and greater than 0.1 hectares (virtually landless).

A range of other dimensions are important attributes of scale in defining smallholder farmers. Among these attributes, geographical attributes, access, use and ownership of capital, livestock, and inputs (including credit) are crucial. Jayne et al. (2003) defined smallholders in a similar way in six Sub-Saharan countries. Eastwood, Lipton, and Newell (2007) and Anriquez and Bonomi (2007) provided useful reviews on the evolution of farm size. Moreover, other attributes, such as land fragmentation or differentiation between land ownership and use, are important characteristics that affect scale in agriculture. Another form of farm 
typologies reflects agro-ecological characteristics, such as climate, farmland related factors (soil, slope, and altitude), and the crop and livestock systems used along with other economic factors. Finally, a set of farm typologies employed by FAO (McConnell \& Dillon, 1997) addresses attributes reflecting the operational objective of the farm and its degree of independence along with its size. The operational objectives of the farm, stemming from the principal purpose of welfare maximization, are achieved through self-sufficiency and/or the generation of some amount of cash income, while the number and the types of crops cultivated are also considered.

\section{Challenges Facing Small Scale Agriculture}

Numerous experts have suggested that modern economic reality and the new ways of doing business in agriculture (and other sectors) imply deteriorating prospects for small scale farmers. Small scale farmers thus face a new range of conditions and challenges that go beyond the paradigm of peasant farming. These hurdles include globalization, technological advances, institutional changes, and environmental concerns (Diao, Hazell, Resnick, \& Thurlow, 2006; McCullough, Pingali, \& Stamoulis, 2008).

During the Green Revolution, technological progress based primarily on improved seeds was easily adapted from farmers irrespective of operational size. Nowadays, changes in methods of production stemming from technological advances affect economies of scale. Recently, technological advances require investments both in human and physical capital, as well as advanced relationships with a wide network of suppliers and traders of inputs and services. In this environment, small scale farmers face difficulties on how to locate the required financial resources and integrate.

In general, there exists a range of factors that promotes large scale efficiency (lumpy inputs, labor specialization, processing and marketing, and capital related transaction costs) and another set that does the opposite (risk considerations and labor related transaction costs). The relative importance of these factors in specific environments may lead to different outcomes. Several authors consider efficiency of small farms as an outcome originating from agro-ecological conditions and the local environment. Nevertheless, further evidence indicates that along transition, other factors come into play that reverse the efficiency advantage of small farms. In particular, labor to capital ratios increase along with the importance of managerial quality attributes seems to favor large scale farming.

Globalization has led to changes in marketing and trading modes as well as affected domestic and international marketing chains. In developing countries, oligopsonistic structures characterize more and more the marketing of agricultural commodities, as chains concentrate on increasing market shares. In these structures, quality, quantity, and timing constraints favor large scale in operations which are able to meet for these requirements and easily adjust when needed.

The recent decade has also been characterized by an increase in volatility, especially in agricultural food commodities. As argued by Aizenman and Pinto (2005), though some may benefit from higher volatility, there is an overall welfare loss. In agriculture, volatile commodity prices are of particular importance in agriculture and particularly in developing countries. This is so for different reasons. Firstly, most of the poor households in developing countries spend large proportions of their incomes on food. Secondly, most farm households in developing countries are small scale farmers who sell their produce onto the market but also happen to be net buyers. Thirdly and lastly, most small scale farm households rely on the sale of food commodities in order to cover their basic needs and expenditures like health and education expenses. Food price volatility thus feeds 
directly into poverty. This is because high food prices can play a major role in moving many vulnerable non-poor households into poverty and low food prices can move non-poor farm households into poverty. Since these households devote a large proportion of their budgets to food, price shocks can easily pre-empt their income moving them from sustainability into poverty (Anderson \& Roumaset, 1996).

As far as agricultural research is concerned, the past decades has observed a shift from yield creation which was the norm during the Green Revolution to yield protection. Moreover, fewer innovations, declining rates of funding and shifts from public to private spending, seem to favor large scale farming systems. Increasing environmental concerns along with changes in climate create another challenge for agricultural systems. With respect to this challenge, scale of operations may have significant implications regarding the viability of different types of farmers. The literature suggests that smallholders may be unable to account and adjust to these environmental threats, due to the lack of sufficient human, social, and financial capital and information. Some degree of optimism is allowed, as long as small scale is able to provide greater flexibility and adaptability.

Finally, a major shift is observed in the policy environment the last decades, which no longer accommodates for extensive public intervention and support unlike the Green Revolution state of affairs. Moreover, promoting private sector intervention and support may adversely affect small scale farming business, as long as the latter fails to comply with the quantity, quality, and timing constraints that private business require or as long as the enabling environment is still missing.

\section{Methodology and Data}

Though farm size is an easy measure of size, it is often unable to capture the different dimensions regarding scale in farming systems. Size of cultivated will be used as the key dimension in identifying the different categories of farmers. The database consists of survey data from several countries. In household survey data, operated or owned land size is reported at the household level. Empirical research employs thresholds at the level of family farm, which, are able to accommodate the organizational form of the farm (family in most of the cases). They, however, miss information with respect to production. This is so as most farms are small, but most production occurs on large farms, the typical measure of representative farm size (the average and median) will tend to mask large changes in the concentration of production. Average and median measures of farm size focus on the typical farm, which is small, rather than the typical hectare of farmland, which is associated with a larger operation.

Country's land median, suggested by Key and Roberts (2007a, 2007b), may better reflect the size of operations where most production occurs. The land median is calculated by first ordering farms from smallest to largest and picking the farm size at the middle hectare (the standard median focuses on the middle farm). By use of the measure, half of all land (rather than farms) are on farms smaller than the land median and half of land are on bigger farms, thus capturing the typical acre of farmland. Conditional on the land distribution and the typical size of the farms within a country, the land median may be higher or lower than the two hectares threshold, but always equal or higher with respect to the other thresholds used.

Doran (1985) suggested a methodology which accounts for the multi-dimensional character of scale, avoiding shortcomings that ad-hoc measures impose. With this methodology, a function $\Phi(Z)$ replaces any ad hoc threshold and estimates the cut-off point from the data. Denoting this cut-off point by $\mu$ and assuming a cumulative normal distribution for the scale variable, then: 


$$
\Phi(\mu, \sigma)=\Phi[(Z-\mu) / \sigma]
$$

where $Z$ refers to a vector of exogenous characteristics; $\mu$ and $\sigma$ refer to the mean; and the standard deviation is $\Phi$. At $95 \%$ confidence interval, small and large farms are those for which holds:

$$
Z<\mu-1.96 \sigma \text { and } Z>\mu+1.96 \sigma
$$

If $\sigma$ is not statistically significant, then two types of farms can be recognized: small and large, with the cut-off point determined by the data. If $\sigma$ is significantly different from zero, then there is a third type of farms, between small and large farms, which may be thought as farms being in the process of changing technology. This methodology will be implemented in the current dataset in next steps of the research.

The data are obtained from the RIGA database developed in FAO. The database consists of a large number of about 25 surveys conducted in more than 15 developing countries in different continents. A major advantage of the database is the detailed and consistent methodology employed to construct the income sources and the associated aggregates (Davis et al., 2007).

This paper uses the survey data for the following countries: Guatemala in 2000, Nicaragua in 2001, Malawi in 2004, and Kenya in 2005. Using the multiple survey datasets, it first constructed a series of variables necessary for this analysis. It then conducts the analysis country by country and then does a cross-country comparative study of the different measures of land distribution. This analysis differs from the others, as it looked at the amount of land cultivated by each household in the surveys conducted, not the amount of land owned. ${ }^{1}$

It estimates four threshold variables on the land cultivated by households:

- 40th percentile;

- mean;

- median;

- hectare-weighted median.

For each of the above surveys and given the thresholds, households are categorized into:

- households that do not cultivate any land;

- households that are classified as small scale farmers;

- households that are classified as large scale farmers.

The variables are then constructed by using the multiple household survey datasets.

\section{Results}

The results of the above estimates are recorded in the tables in the following. Table 1 shows the distribution in population for each of the four country surveys using the different threshold measures. It is interesting to see how the proportions change when it implements different threshold measures (see Figure 1). The 40th percentile and median threshold highlight similar results, while mean and hectare-weighted median provide evidence of similar population distributions across all countries. What emerges in the cross-country comparison is the consistently high proportion of small scale farmers in these contexts. In particular, with the hectare-weighted median threshold, small scale farmers in all four countries represent more than $60 \%$ of the population in the rural areas.

\footnotetext{
${ }^{1}$ This question is particularly relevant in the African context where many of the households and small scale farmers do not have ownership rights over the land or communally cultivate the land.
} 


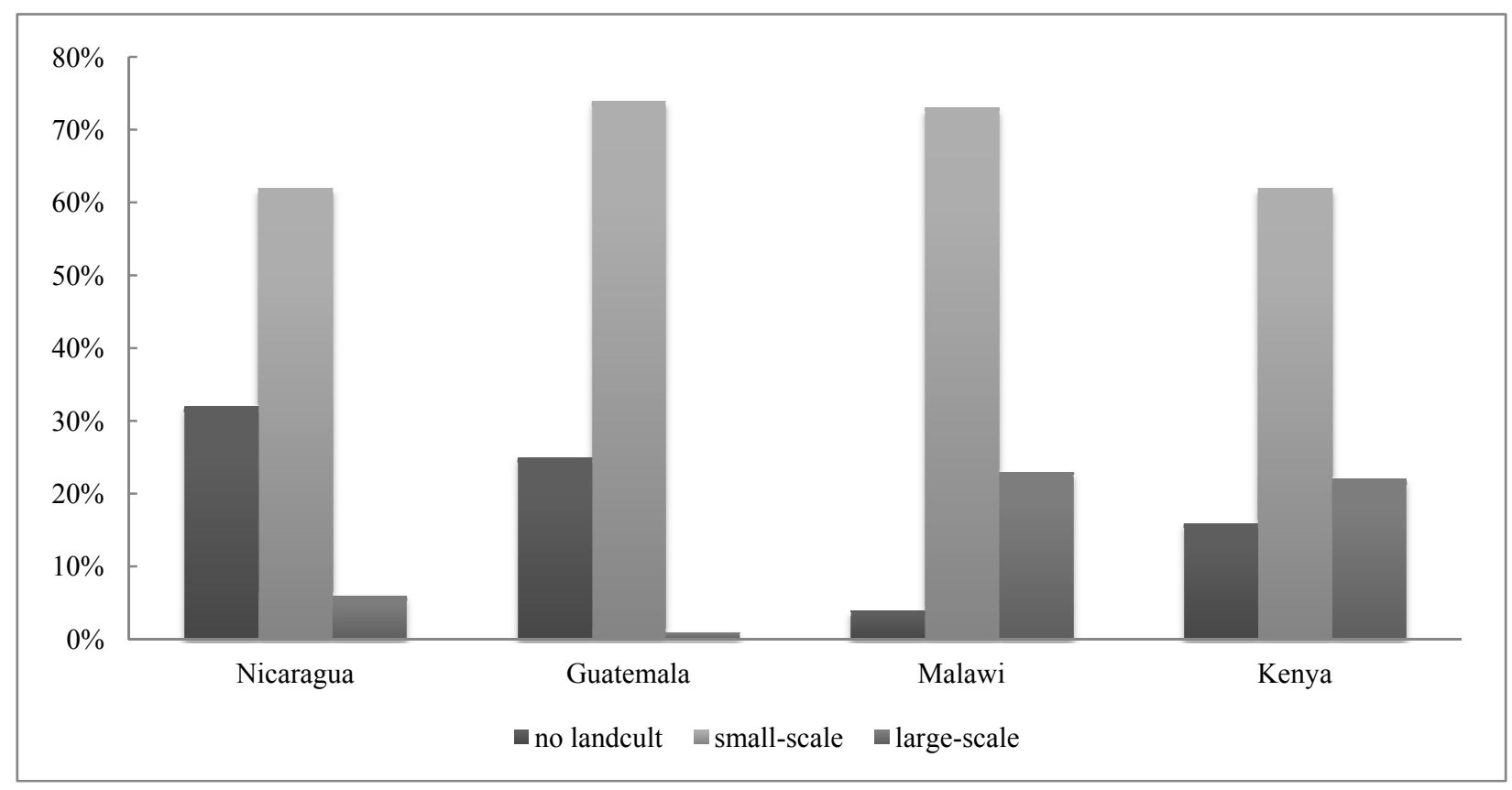

Figure 1. Population distribution.

Table 1

Population Distribution

\begin{tabular}{llccc}
\hline Country & Threshold & No land & Small scale & Large scale \\
\hline \multirow{5}{*}{ Nicaragua } & Mth percentile & $32.00 \%$ & $25.00 \%$ & $43.00 \%$ \\
& Mean & $32.00 \%$ & $53.00 \%$ & $15.00 \%$ \\
& Median & $32.00 \%$ & $32.00 \%$ & $36.00 \%$ \\
& Hectare-weighted median & $32.00 \%$ & $62.00 \%$ & $6.00 \%$ \\
\hline \multirow{5}{*}{ Guatemala } & 40th percentile & $25.00 \%$ & $28.00 \%$ & $47.00 \%$ \\
& Mean & $25.00 \%$ & $68.00 \%$ & $7.00 \%$ \\
& Median & $25.00 \%$ & $34.00 \%$ & $41.00 \%$ \\
\multirow{5}{*}{ Malawi } & Hectare-weighted median & $25.00 \%$ & $74.00 \%$ & $1.00 \%$ \\
& 40th percentile & $4.00 \%$ & $36.00 \%$ & $60.00 \%$ \\
& Mean & $4.00 \%$ & $58.00 \%$ & $38.00 \%$ \\
\multirow{5}{*}{ Kenya } & Median & $4.00 \%$ & $46.00 \%$ & $50.00 \%$ \\
& Hectare-weighted median & $4.00 \%$ & $73.00 \%$ & $23.00 \%$ \\
\hline & 40th percentile & $16.00 \%$ & $31.00 \%$ & $53.00 \%$ \\
& Mean & $16.00 \%$ & $53.00 \%$ & $31.00 \%$ \\
& Median & $16.00 \%$ & $36.00 \%$ & $48.00 \%$ \\
\hline
\end{tabular}

Table 2 highlights some of the key household and demographic characteristics using each of the thresholds across the four surveys. Some of these characteristics include: the average number of members in each household, female headed households, years of education of the head of household, access to infrastructure, and poverty headcount. In particular, the infrastructure index tries to capture a range of associated services (such as education, health, and other public facilities), and whether households can access them or not (Zezza et al., 2007). 
Table 2

Household Characteristics

\begin{tabular}{|c|c|c|c|c|c|c|c|c|c|c|c|c|}
\hline \multirow[b]{2}{*}{ Characteristics (Nicaragua) } & \multicolumn{3}{|c|}{ 40th percentile } & \multicolumn{3}{|c|}{ Mean } & \multicolumn{3}{|c|}{ Median } & \multicolumn{3}{|c|}{ Hectare-weighted median } \\
\hline & No land & $\begin{array}{l}\text { Small } \\
\text { scale }\end{array}$ & $\begin{array}{l}\text { Large } \\
\text { scale }\end{array}$ & No land & $\begin{array}{l}\text { Small } \\
\text { scale }\end{array}$ & $\begin{array}{l}\text { Large } \\
\text { scale }\end{array}$ & No land & $\begin{array}{l}\text { Small } \\
\text { scale }\end{array}$ & $\begin{array}{l}\text { Large } \\
\text { scale }\end{array}$ & No land & $\begin{array}{l}\text { Small } \\
\text { scale }\end{array}$ & $\begin{array}{l}\text { Large } \\
\text { scale }\end{array}$ \\
\hline Number of people in the household & 4.93 & 5.6 & 6.4 & 4.93 & 5.75 & 6.39 & 4.93 & 6 & 6.34 & 4.93 & 6.06 & 6.24 \\
\hline Female headed household & 0.29 & 0.16 & 0.11 & 0.29 & 0.15 & 0.11 & 0.29 & 0.14 & 0.11 & 0.29 & 0.13 & 0.12 \\
\hline Years of education head of household & 3.31 & 2.14 & 2.01 & 3.31 & 2.15 & 1.97 & 3.31 & 2.05 & 2.09 & 3.31 & 2.02 & 2.5 \\
\hline Tropical livestock units: total & 0.04 & 0.96 & 5.13 & 0.04 & 1.09 & 5.74 & 0.04 & 2.06 & 8.41 & 0.04 & 2.61 & 12.11 \\
\hline Mechanic & 0.01 & 0.31 & 0.53 & 0.01 & 0.34 & 0.54 & 0.01 & 0.39 & 0.61 & 0.01 & 0.42 & 0.72 \\
\hline Fertile 1 & 0.05 & 0.42 & 0.4 & 0.05 & 0.43 & 0.39 & 0.05 & 0.42 & 0.38 & 0.05 & 0.41 & 0.41 \\
\hline Fertile 2 & 0.03 & 0.06 & 0.06 & 0.03 & 0.07 & 0.06 & 0.03 & 0.06 & 0.08 & 0.03 & 0.06 & 0.1 \\
\hline Fertile 3 & 0.02 & 0.45 & 0.5 & 0.02 & 0.45 & 0.5 & 0.02 & 0.46 & 0.56 & 0.02 & 0.47 & 0.61 \\
\hline Access to infrastructure index & 0.27 & -0.07 & -0.22 & 0.27 & -0.07 & -0.25 & 0.27 & -0.1 & -0.35 & 0.27 & -0.13 & -0.4 \\
\hline Poverty headcount & 0.48 & 0.71 & 0.62 & 0.48 & 0.7 & 0.61 & 0.48 & 0.68 & 0.56 & 0.48 & 0.67 & 0.45 \\
\hline Crop income/Total income & 0.04 & 0.22 & 0.35 & 0.04 & 0.24 & 0.36 & 0.04 & 0.28 & 0.36 & 0.04 & 0.3 & 0.34 \\
\hline Livestock income/Total income & 0.04 & 0.16 & 0.33 & 0.04 & 0.16 & 0.35 & 0.04 & 0.21 & 0.43 & 0.04 & 0.24 & 0.42 \\
\hline On-farm income/Total income & 0.08 & 0.38 & 0.68 & 0.08 & 0.41 & 0.71 & 0.08 & 0.5 & 0.78 & 0.08 & 0.54 & 0.76 \\
\hline Off-farm income/Total income & 0.92 & 0.62 & 0.31 & 0.92 & 0.59 & 0.28 & 0.92 & 0.5 & 0.2 & 0.92 & 0.46 & 0.23 \\
\hline \multirow[b]{2}{*}{ Characteristics (Guatemala) } & \multicolumn{3}{|c|}{ 40th percentile } & \multicolumn{3}{|c|}{ Mean } & \multicolumn{3}{|c|}{ Median } & \multicolumn{3}{|c|}{ Hectare-weighted median } \\
\hline & No land & $\begin{array}{l}\text { Small } \\
\text { scale }\end{array}$ & $\begin{array}{l}\text { Large } \\
\text { scale }\end{array}$ & No land & $\begin{array}{l}\text { Small } \\
\text { scale }\end{array}$ & $\begin{array}{l}\text { Large } \\
\text { scale }\end{array}$ & No land & $\begin{array}{l}\text { Small } \\
\text { scale }\end{array}$ & $\begin{array}{l}\text { Large } \\
\text { scale }\end{array}$ & No land & $\begin{array}{l}\text { Small } \\
\text { scale }\end{array}$ & $\begin{array}{l}\text { Large } \\
\text { scale }\end{array}$ \\
\hline Number of people in the household & 4.82 & 5.54 & 6.18 & 4.82 & 5.91 & 6.11 & 4.82 & 5.64 & 6.19 & 4.82 & 5.95 & 4.54 \\
\hline Female headed household & 0.23 & 0.17 & 0.07 & 0.23 & 0.12 & 0.06 & 0.23 & 0.15 & 0.07 & 0.23 & 0.11 & 0.12 \\
\hline Years of education head of household & 3.39 & 1.92 & 1.72 & 3.39 & 1.81 & 1.72 & 3.39 & 1.9 & 1.71 & 3.39 & 1.81 & 1.05 \\
\hline Tropical livestock units: total & 0.22 & 0.46 & 1.72 & 0.22 & 0.7 & 6.25 & 0.22 & 0.5 & 1.85 & 0.22 & 0.82 & 27.71 \\
\hline Mechanic & 0.01 & 0.84 & 0.8 & 0.01 & 0.83 & 0.65 & 0.01 & 0.85 & 0.78 & 0.01 & 0.82 & 0.91 \\
\hline Fertile 1 & 0.01 & 0.77 & 0.74 & 0.01 & 0.77 & 0.6 & 0.01 & 0.78 & 0.73 & 0.01 & 0.75 & 0.82 \\
\hline Fertile 2 & 0.01 & 0.27 & 0.53 & 0.01 & 0.4 & 0.67 & 0.01 & 0.29 & 0.55 & 0.01 & 0.43 & 0.69 \\
\hline Fertile 3 & 0 & 0.11 & 0.13 & 0 & 0.11 & 0.19 & 0 & 0.11 & 0.13 & 0 & 0.11 & 0.47 \\
\hline Access to infrastructure index & 0.17 & 0.12 & -0.2 & 0.17 & -0.04 & -0.38 & 0.17 & 0.08 & -0.22 & 0.17 & -0.08 & 0.1 \\
\hline Poverty headcount & 0.47 & 0.72 & 0.74 & 0.47 & 0.75 & 0.61 & 0.47 & 0.73 & 0.73 & 0.47 & 0.74 & 0.25 \\
\hline
\end{tabular}




\begin{tabular}{|c|c|c|c|c|c|c|c|c|c|c|c|c|}
\hline \multirow[b]{2}{*}{ Characteristics (Guatemala) } & \multicolumn{3}{|c|}{ 40th percentile } & \multicolumn{3}{|c|}{ Mean } & \multicolumn{3}{|c|}{ Median } & \multicolumn{3}{|c|}{ Hectare-weighted median } \\
\hline & No land & $\begin{array}{l}\text { Small } \\
\text { scale }\end{array}$ & $\begin{array}{l}\text { Large } \\
\text { scale }\end{array}$ & No land & $\begin{array}{l}\begin{array}{l}\text { Small } \\
\text { scale }\end{array} \\
\end{array}$ & $\begin{array}{l}\text { Large } \\
\text { scale }\end{array}$ & No land & $\begin{array}{l}\text { Small } \\
\text { scale }\end{array}$ & $\begin{array}{l}\text { Large } \\
\text { scale }\end{array}$ & No land & $\begin{array}{l}\text { Small } \\
\text { scale }\end{array}$ & $\begin{array}{l}\text { Large } \\
\text { scale }\end{array}$ \\
\hline Crop income/Total income & 0.07 & 0.25 & 0.43 & 0.07 & 0.34 & 0.5 & 0.07 & 0.27 & 0.44 & 0.07 & 0.36 & 0.37 \\
\hline Livestock income/Total income & 0.01 & 0.03 & 0.07 & 0.01 & 0.04 & 0.21 & 0.01 & 0.04 & 0.08 & 0.01 & 0.05 & 0.57 \\
\hline On-farm income/Total income & 0.09 & 0.29 & 0.5 & 0.09 & 0.38 & 0.7 & 0.09 & 0.31 & 0.51 & 0.09 & 0.41 & 0.95 \\
\hline Off-farm income/Total income & 0.9 & 0.71 & 0.5 & 0.9 & 0.61 & 0.3 & 0.9 & 0.69 & 0.48 & 0.9 & 0.59 & 0.05 \\
\hline sh_foodexp & 0.51 & 0.53 & 0.56 & 0.51 & 0.54 & 0.58 & 0.51 & 0.53 & 0.56 & 0.51 & 0.55 & 0.51 \\
\hline \multirow[b]{2}{*}{ Characteristics (Malawi) } & \multicolumn{3}{|c|}{ 40th percentile } & \multicolumn{3}{|c|}{ Mean } & \multicolumn{3}{|c|}{ Median } & \multicolumn{3}{|c|}{ Hectare-weighted median } \\
\hline & No land & $\begin{array}{l}\text { Small } \\
\text { scale }\end{array}$ & $\begin{array}{l}\text { Large } \\
\text { scale }\end{array}$ & No land & $\begin{array}{l}\text { Small } \\
\text { scale }\end{array}$ & $\begin{array}{l}\text { Large } \\
\text { scale }\end{array}$ & No land & $\begin{array}{l}\text { Small } \\
\text { scale }\end{array}$ & $\begin{array}{l}\text { Large } \\
\text { scale }\end{array}$ & No land & $\begin{array}{l}\text { Small } \\
\text { scale }\end{array}$ & $\begin{array}{l}\text { Large } \\
\text { scale }\end{array}$ \\
\hline Number of people in the household & 3.32 & 4 & 5 & 3.32 & 4.22 & 5.24 & 3.32 & 4.11 & 5.1 & 3.32 & 4.36 & 5.36 \\
\hline Female headed household & 0.22 & 0.29 & 0.2 & 0.22 & 0.27 & 0.19 & 0.22 & 0.28 & 0.2 & 0.22 & 0.26 & 0.18 \\
\hline Years of education head of household & 6.06 & 3.88 & 4.31 & 6.06 & 3.88 & 4.59 & 6.06 & 3.86 & 4.43 & 6.06 & 3.96 & 4.75 \\
\hline Tropical Livestock Units: total & 0.06 & 0.14 & 0.48 & 0.06 & 0.19 & 0.61 & 0.06 & 0.16 & 0.54 & 0.06 & 0.25 & 0.67 \\
\hline Mechanic & 0.02 & 0.01 & 0.04 & 0.02 & 0.02 & 0.06 & 0.02 & 0.02 & 0.05 & 0.02 & 0.02 & 0.07 \\
\hline Fertile 1 & 0.03 & 0.6 & 0.72 & 0.03 & 0.63 & 0.74 & 0.03 & 0.62 & 0.73 & 0.03 & 0.64 & 0.77 \\
\hline Fertile 2 & 0.02 & 0.53 & 0.65 & 0.02 & 0.56 & 0.67 & 0.02 & 0.55 & 0.66 & 0.02 & 0.57 & 0.71 \\
\hline Fertile 3 & 0 & 0.01 & 0.05 & 0 & 0.02 & 0.06 & 0 & 0.02 & 0.05 & 0 & 0.03 & 0.06 \\
\hline Access to infrastructure index & 0.85 & -0.02 & -0.07 & 0.85 & -0.04 & -0.05 & 0.85 & -0.03 & -0.06 & 0.85 & -0.05 & -0.01 \\
\hline Poverty headcount & 0.27 & 0.51 & 0.46 & 0.27 & 0.5 & 0.44 & 0.27 & 0.51 & 0.45 & 0.27 & 0.5 & 0.41 \\
\hline Crop income/Total income & 0.19 & 0.53 & 0.61 & 0.19 & 0.55 & 0.62 & 0.19 & 0.54 & 0.62 & 0.19 & 0.56 & 0.63 \\
\hline Livestock income/Total Income & -1.01 & -0.37 & -0.55 & -1.01 & -0.35 & -0.72 & -1.01 & -0.3 & -0.68 & -1.01 & -0.4 & -0.75 \\
\hline On-farm income/Total income & -0.82 & 0.16 & 0.06 & -0.82 & 0.21 & -0.1 & -0.82 & 0.24 & -0.06 & -0.82 & 0.16 & -0.12 \\
\hline Off-farm income/Total income & 1.79 & 0.84 & 0.94 & 1.79 & 0.79 & 1.1 & 1.79 & 0.75 & 1.06 & 1.79 & 0.84 & 1.11 \\
\hline Foodexp percapita/Totalexp percapita & 0.59 & 0.62 & 0.61 & 0.59 & 0.62 & 0.61 & 0.59 & 0.62 & 0.61 & 0.59 & 0.62 & 0.6 \\
\hline
\end{tabular}


Table 2 presents these characteristics at country level and implementing the four different thresholds. In all the four countries landless, over $50 \%$ of their (the smallholders and large scale farmers) total expenditure went to food. The poverty headcount indices show that small scale farmers are among the poorest in these contexts with indices that are over 0.5 .

Table 3

Land Distribution by Threshold (\%)

\begin{tabular}{lllcl}
\hline Country & Threshold & No land & Small scale & Large scale \\
\hline \multirow{3}{*}{ Nicaragua } & Mth percentile & $0.00 \%$ & $3.00 \%$ & $97.00 \%$ \\
& Mean & $0.00 \%$ & $18.00 \%$ & $82.00 \%$ \\
& Median & $0.00 \%$ & $5.00 \%$ & $95.00 \%$ \\
& Hectare-weighted median & $0.00 \%$ & $59.00 \%$ & $41.00 \%$ \\
\hline \multirow{3}{*}{ Guatemala } & 40th percentile & $0.00 \%$ & $1.00 \%$ & $99.00 \%$ \\
& Mean & $0.00 \%$ & $11.00 \%$ & $89.00 \%$ \\
& Median & $0.00 \%$ & $2.00 \%$ & $98.00 \%$ \\
\multirow{3}{*}{ Malawi } & Hectare-weighted median & $0.00 \%$ & $44.00 \%$ & $56.00 \%$ \\
\hline \multirow{5}{*}{ Kenya } & 40th percentile & $0.00 \%$ & $15.00 \%$ & $85.00 \%$ \\
& Mean & $0.00 \%$ & $32.00 \%$ & $68.00 \%$ \\
& Median & $0.00 \%$ & $22.00 \%$ & $78.00 \%$ \\
& Hectare-weighted median & $0.00 \%$ & $52.00 \%$ & $48.00 \%$ \\
\hline
\end{tabular}

Table 4

Average Farm Size of the Land Cultivated (in Hectares)

\begin{tabular}{lllcr}
\hline Country & Threshold & No land & Small scale & Large scale \\
\hline \multirow{3}{*}{ Nicaragua } & 40th percentile & 0.00000 & 1.03112 & 17.59311 \\
& Mean & 0.00000 & 2.82487 & 40.03744 \\
& Median & 0.00000 & 1.23462 & 20.34439 \\
& Hectare-weighted median & 0.00000 & 5.93483 & 62.67598 \\
\hline \multirow{3}{*}{ Guatemala } & 40th percentile & 0.00000 & 0.26644 & 8.42721 \\
& Mean & 0.00000 & 0.98911 & 46.34349 \\
& Median & 0.00000 & 0.32498 & 9.52282 \\
Malawi & Hectare-weighted median & 0.00000 & 2.59878 & 179.05530 \\
& 40th percentile & 0.00000 & 0.25316 & 1.03592 \\
& Mean & 0.00000 & 0.35271 & 1.36342 \\
& Median & 0.00000 & 0.29647 & 1.16263 \\
Kenya & Hectare-weighted median & 0.00000 & 0.44176 & 1.68039 \\
& 40th percentile & 0.00000 & 0.27241 & 1.45035 \\
& Mean & 0.00000 & 0.43378 & 2.07379 \\
\hline
\end{tabular}


In Table 3, the average farm size in hectares cultivated is calculated for each of the categories (no land, small scale, and large scale) and for each of the thresholds. Table 3 shows the results for each country survey. In all four country studies and for all the thresholds, there is evidence of inequality in the average farm sizes cultivated by small farmers compared to those cultivated by large scale farmers.

Table 4 shows that with the 40th percentile threshold, small scale farmers on average cultivate as low as 1.03 hectares compared to the large scale farmers who cultivate 18 hectares of land. This result is consistent across all the thresholds used where one can observe the highest values, when the hectare-weighted median is implemented. In this case, smallholder farmers cultivate 6 hectares while large scale farmers cultivate 63 hectares of land. The average farm size cultivated by smallholders in all four countries is significantly smaller compared to hectares cultivated by their large scale counterparts.

Table 5

Contribution of Income Sources (Average) at Household Level (HWM)

\begin{tabular}{|c|c|c|c|c|}
\hline Contribution & Country & No land & Small scale & Large scale \\
\hline \multirow{4}{*}{$\begin{array}{l}\text { Share of on-farm } \\
\text { income (average) }\end{array}$} & Guatemala & 0.09 & 0.42 & 0.75 \\
\hline & Nicaragua & 0.08 & 0.55 & 0.85 \\
\hline & Kenya & 0.24 & 0.58 & 0.65 \\
\hline & Malawi & 0.24 & 0.66 & 0.78 \\
\hline \multirow{4}{*}{$\begin{array}{l}\text { Share of crop } \\
\text { income (average) }\end{array}$} & Guatemala & 0.07 & 0.36 & 0.46 \\
\hline & Nicaragua & 0.04 & 0.3 & 0.35 \\
\hline & Kenya & 0.13 & 0.4 & 0.45 \\
\hline & Malawi & 0.2 & 0.56 & 0.64 \\
\hline \multirow{4}{*}{$\begin{array}{l}\text { Share of livestock } \\
\text { income (average) }\end{array}$} & Guatemala & 0.02 & 0.06 & 0.3 \\
\hline & Nicaragua & 0.04 & 0.25 & 0.5 \\
\hline & Kenya & 0.11 & 0.18 & 0.2 \\
\hline & Malawi & 0.04 & 0.09 & 0.14 \\
\hline \multirow{4}{*}{$\begin{array}{l}\text { Share of on-farm } \\
\text { income sales (average) }\end{array}$} & Guatemala & 0.01 & 0.3 & 0.53 \\
\hline & Nicaragua & 0.04 & 0.35 & 1 \\
\hline & Kenya & 0.18 & 0.29 & 0.42 \\
\hline & Malawi & 0.01 & 0.12 & 0.22 \\
\hline \multirow{4}{*}{$\begin{array}{l}\text { Share of crop } \\
\text { income sales (average) }\end{array}$} & Guatemala & 0 & 0.26 & 0.25 \\
\hline & Nicaragua & 0.03 & 0.21 & 0.36 \\
\hline & Kenya & 0 & 0.21 & 0.33 \\
\hline & Malawi & 0 & 0.1 & 0.18 \\
\hline \multirow{4}{*}{$\begin{array}{l}\text { Share of livestock } \\
\text { income sales (average) }\end{array}$} & Guatemala & 0.01 & 0.04 & 0.28 \\
\hline & Nicaragua & 0.01 & 0.13 & 0.64 \\
\hline & Kenya & 0.18 & 0.08 & 0.1 \\
\hline & Malawi & 0 & 0.02 & 0.03 \\
\hline \multirow{4}{*}{$\begin{array}{l}\text { Share of off-farm } \\
\text { income (average) }\end{array}$} & Guatemala & 0.9 & 0.58 & 0.25 \\
\hline & Nicaragua & 0.91 & 0.44 & 0.11 \\
\hline & Kenya & 0.62 & 0.34 & 0.26 \\
\hline & Malawi & 0.72 & 0.33 & 0.21 \\
\hline
\end{tabular}


Table 5 documents the average contribution of income sources to the household's income. It focuses on the hectare weighted median threshold. Similar analysis has been replicated for the other three thresholds across the country surveys. Looking at on-farm (crop and livestock) income contributions, one can observe that this share is highest for large scale farmer. It is interesting to observe that on-farming income accounts for over $40 \%$ of the small scale household's income source across all the countries surveyed. These results are confirmed by the disaggregate measures of the average share of crop and livestock income. The share of crop income prevails over the contribution from livestock income with shares as high as $56 \%$ in Malawi. Another set of results highlights the average share of on-farm income. Large scale households have a higher share of onfarm income sales compared to small scale farmers. Limited access to markets and various other constraints significantly limit the benefits that may arise from commercialization for small scale farmers. These constraints vary from one region to another.

Table 5 highlights the share of off-farm income on the household's average income sales. In all four survey countries, households that do not cultivate land have the highest share of off-farm income. This share is as high as $90 \%$ in Guatemala and Nicaragua and above $60 \%$ in Kenya and Malawi. Small scale households follow with over $30 \%$ of their income coming from off-farm activities. Large scale farmers have the smallest share.

Table 6

Distribution of Income Sources in the Rural Economy

\begin{tabular}{llccc}
\hline Distribution & Country & No land & Small scale & Large scale \\
\hline \multirow{2}{*}{$\begin{array}{l}\text { Rural income } \\
\text { distribution }\end{array}$} & Guatemala & $33.00 \%$ & $64.00 \%$ & $3.00 \%$ \\
& Nicaragua & $35.00 \%$ & $60.00 \%$ & $5.00 \%$ \\
& Kenya & $20.00 \%$ & $65.00 \%$ & $16.00 \%$ \\
Malawi & $5.00 \%$ & $69.00 \%$ & $26.00 \%$ \\
Share of on-farm & Guatemala & $7.00 \%$ & $88.00 \%$ & $5.00 \%$ \\
income (average) & Nicaragua & $6.00 \%$ & $83.00 \%$ & $11.00 \%$ \\
& Kenya & $10.00 \%$ & $73.00 \%$ & $17.00 \%$ \\
\hline \multirow{3}{*}{ Share of crop } & Malawi & $2.00 \%$ & $67.00 \%$ & $31.00 \%$ \\
\hline income (average) & Guatemala & $6.00 \%$ & $90.00 \%$ & $4.00 \%$ \\
& Nicaragua & $6.00 \%$ & $86.00 \%$ & $8.00 \%$ \\
\hline Kenya & $7.00 \%$ & $75.00 \%$ & $18.00 \%$ \\
income (average) & Malawi & $1.00 \%$ & $68.00 \%$ & $31.00 \%$ \\
\hline Share of off-farm & Guatemala & $11.00 \%$ & $79.00 \%$ & $10.00 \%$ \\
income (average) & Kicaragua & $6.00 \%$ & $80.00 \%$ & $15.00 \%$ \\
& Kenya & $14.00 \%$ & $70.00 \%$ & $16.00 \%$ \\
\hline & Malawi & $2.00 \%$ & $63.00 \%$ & $35.00 \%$ \\
\hline
\end{tabular}

Table 6 shows the distribution of income in the general economy. Looking at the general income distribution in the rural economies of the case studies, it finds that smallholder farmers contribute heavily to the 
rural income (see Figure 2). Most of this income comes from on-farm income activities with a majority of this income coming from crop sales. These results are consistent across all the countries.

Table 7 confirms the important role of the farm and crop income from smallholder farmers in their contribution to the rural aggregate income. The shares are above $20 \%$ and $15 \%$ respectively. Though at smaller magnitudes, small scale farmer's farm and crop income contribution to the national aggregates. In some cases, for example Malawi, it exceeds $30 \%$ (see Table 8 for details).

Table 9 makes a cross-country comparison of the proportion of food expenditure as a share of total expenditure. In all countries the share is above $50 \%$ for all the categories. In some countries the share for small scale households is the highest.

Table 10 makes a cross-country comparison of the poverty headcount ratios for each of the categories. In all countries, the headcount ratio is highest in small scale farmers compared to the large scale households and those that do not cultivate any land.

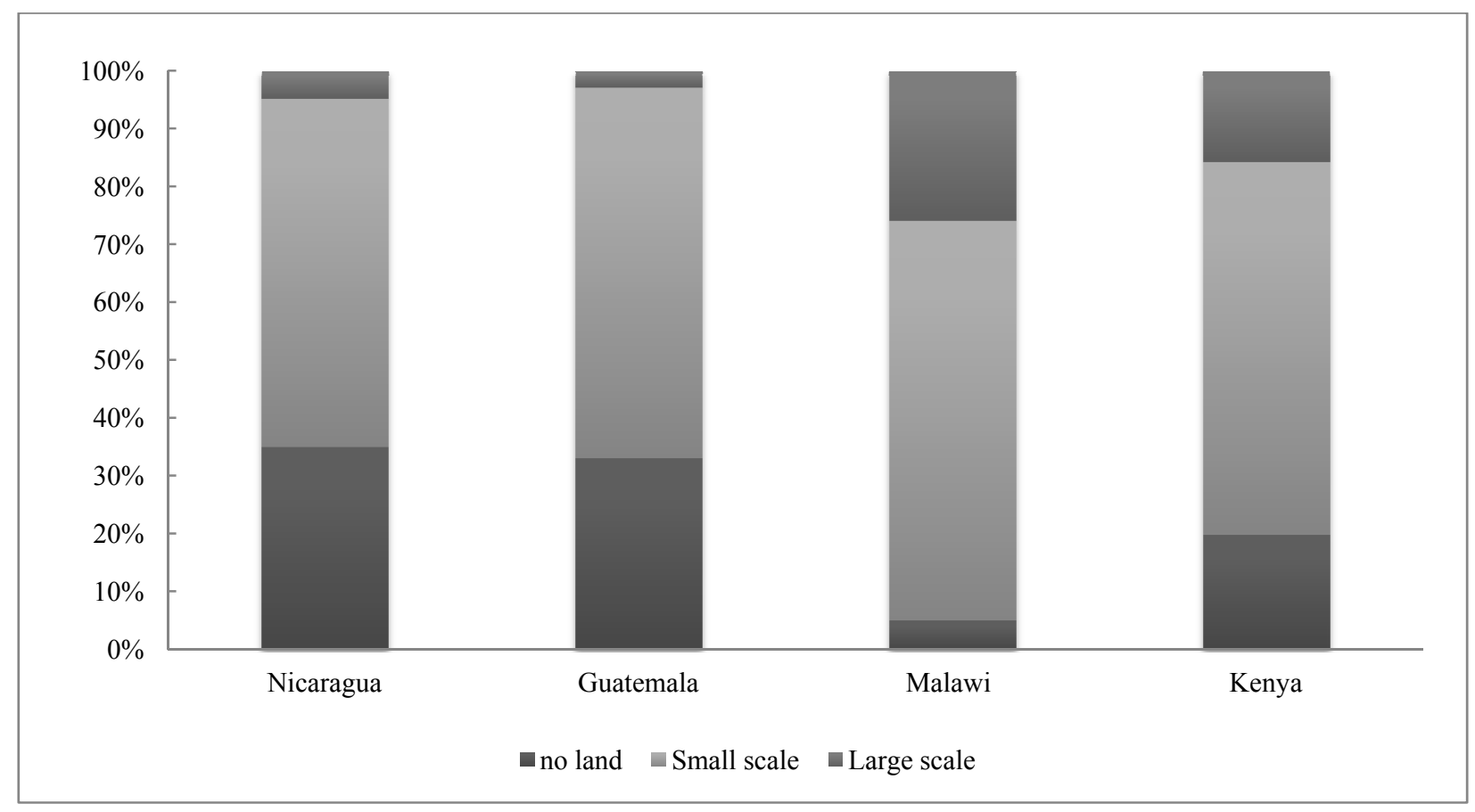

Figure 2. Rural income distribution.

Table 7

Contribution of Income to the Rural Income (Aggregate)

\begin{tabular}{llllc}
\hline Proportion & Country & No land & Small scale & Large scale \\
\hline \multirow{3}{*}{$\begin{array}{l}\text { Proportion of farm } \\
\text { income }\end{array}$} & Guatemala & $2.00 \%$ & $23.00 \%$ & $1.00 \%$ \\
& Nicaragua & $2.00 \%$ & $32.00 \%$ & $4.00 \%$ \\
& Kenya & $4.00 \%$ & $28.00 \%$ & $6.00 \%$ \\
& Malawi & $1.00 \%$ & $44.00 \%$ & $20.00 \%$ \\
\hline \multirow{3}{*}{$\begin{array}{l}\text { Proportion of crop } \\
\text { income }\end{array}$} & Guatemala & $1.00 \%$ & $20.00 \%$ & $1.00 \%$ \\
& Nicaragua & $1.00 \%$ & $17.00 \%$ & $2.00 \%$ \\
& Kenya & $2.00 \%$ & $17.00 \%$ & $4.00 \%$ \\
\hline
\end{tabular}


Table 8

Contribution of Income to the National Income (Aggregate)

\begin{tabular}{llccc}
\hline Proportion & Country & No land & Small scale & Large scale \\
\hline \multirow{3}{*}{$\begin{array}{l}\text { Proportion of farm } \\
\text { income }\end{array}$} & Guatemala & $0.75 \%$ & $9.29 \%$ & $0.54 \%$ \\
& Nicaragua & $0.73 \%$ & $10.50 \%$ & $1.46 \%$ \\
& Kenya & $2.00 \%$ & $12.00 \%$ & $3.00 \%$ \\
& Malawi & $1.00 \%$ & $36.00 \%$ & $17.00 \%$ \\
\hline \multirow{3}{*}{$\begin{array}{l}\text { Proportion of crop } \\
\text { income }\end{array}$} & Guatemala & $0.56 \%$ & $7.95 \%$ & $0.37 \%$ \\
& Nicaragua & $0.38 \%$ & $5.49 \%$ & $0.54 \%$ \\
& Kenya & $1.00 \%$ & $7.00 \%$ & $2.00 \%$ \\
Proportion of off-farm & $1.00 \%$ & $30.00 \%$ & $13.00 \%$ \\
\hline income & Malawi & $12.78 \%$ & $16.83 \%$ & $0.53 \%$ \\
& Guatemala & $10.88 \%$ & $9.22 \%$ & $0.25 \%$ \\
\hline
\end{tabular}

Table 9

Proportion of Food Expenditure to Total Expenditure

\begin{tabular}{llll}
\hline Country & No land & Small scale & Large scale \\
\hline Guatemala & 0.51 & 0.54 & 0.57 \\
Nicaragua & - & - & - \\
Kenya & 0.69 & 0.68 & 0.64 \\
Malawi & 0.59 & 0.62 & 0.61 \\
\hline
\end{tabular}

Table 10

Poverty Headcount Indices

\begin{tabular}{llll}
\hline Country & No land & Small scale & Large scale \\
\hline Guatemala & 0.47 & 0.74 & 0.52 \\
Nicaragua & 0.48 & 0.67 & 0.5 \\
Kenya & - & - & - \\
Malawi & 0.27 & 0.5 & 0.42 \\
\hline
\end{tabular}

\section{Conclusions}

The recent agricultural food commodity price spikes have raised the attention on smallholders and on their position as food producers and consumers. In particular academics, policy makers and leaders around the world have underlined the importance of small farmers in achieving global food security and have called for a new global partnership towards improving their productivity and incomes. Smallholder farmers are mainly concentrated in developing countries and account for two thirds of the developing world's three billion rural population.

It empirically and directly identifies and characterizes small scale farmers in developing countries. Using the attribute of land cultivated in hectares, it estimates four main thresholds. Using survey data that were collected and compiled by the RIGA-FAO, it implements the above thresholds to four developing country household surveys in order to first categorize rural households as households that do not cultivate land, 
smallholders, and largeholders. It then addresses multi dimensionality that characterizes small scale farmers, by trying to take into account a series of characteristics which will provide more reliable classification outcomes. It conducts this analysis for each country given the four thresholds. It further conducts a cross-country survey comparison analysis based on one of the thresholds, i.e., the hectare-weighted-median.

One of the key findings is that smallholder farmers are still the majority in terms of population in rural areas. This result is consistent across thresholds as well as in all the four country surveys. Moreover, small scale farmers heavily depend on farming activities as their main source of livelihood. This result is confirmed by the high share of crop and livestock income on the average household income in all the surveyed countries. Small scale farmers also contribute heavily to both rural and national income in these developing countries. On average, the smallholder farmers income contributed by over $20 \%$ and $10 \%$ respectively.

Though these results highlight the important role played by small scale agriculture in the rural economy and its potential in driving economic growth and guaranteeing food security, it also finds evidence of land inequality in the surveyed countries, i.e., the amount of land households cultivate. The inequality varies across countries, mainly due to differences in property rights, the existence of other forms of land tenure, such as share cropping and communal usage of land. In addition, even though smallholders are important to the communities, they are the poorest. The highest levels of poverty rates are in small scale households.

Agriculture in developing countries remains dominated by small scale farms. Yet, productivity remains low and poverty, vulnerability as well as food insecurity remains rampant. The question on whether or not smallholder farmers will persist and remain competitive is hard to tell. On one hand, the Green Revolution in Asia shaped small scale farmers while increasingly commercialized farms. On the other hand, the experience of Brazil suggests that policies that facilitate transition from small to large scale farming led to successful commercialization of the Brazilian agricultural sector. This all trickles down to the crucial and important role of policies. There is a need for appropriate policy measures which would address the issues and challenges smallholder farmers face. Pro-poor policies and strategies that integrate smallholders into markets or strengthen rural off-farm employment are essential to include small scale farmers in the development process.

\section{References}

Aizenman, J., \& Pinto, B. (2005). Managing economic volatility and crises: A practitioner's guide. Cambridge: Cambridge University Press.

Anderson, J., \& Roumaset, J. (1996). Food insecurity and stochastic aspects of poverty (MPRA Paper 13323, University Library of Munich, Germany).

Anriquez, G., \& Bonomi, G. (2007). Long-term farming trends: An inquiry using agricultural censuses (ESA FAO working paper).

Chamberlin, J. (2008). It's a small world after all: Defining smallholder agriculture in Ghana (IFPRI discussion papers 823, International Food Policy Research Institute (IFPRI)).

Davis, B., Winters, P., Carletto, G., Covarrubias, K., Quinones, E., Zezza,. . . DiGiuseppe, S. (2007). Rural income-generating activities: A cross country comparison. Retrieved from http://www.fao.org/3/a-ai195e.pdf

Diao, X., Hazell, P., Resnick, D., \& Thurlow, J. (2006). The role of agriculture in development: Implications for Sub-Saharan Africa. Retrieved from http://www.ifpri.org/sites/default/files/pubs/pubs/abstract/153/rr153.pdf

Doran, H. E. (1985). "Small” or "large" farm: Some methodological considerations. American Journal of Agricultural Economics, 67(1), 130-132.

Eastwood, R., Lipton, M., \& Newell, A. (2007). Farm size. In R. Evenson and P. Pingali (Eds.), Agricultural development: Farmers, farm production and farm markets. Amsterdam: Elsevier. 
Fan, S., \& Chan-Kang, C. (2005). Is small beautiful? Farm size, productivity, and poverty in Asian agriculture. Agricultural Economics, 32(1), 135-146.

Hazell, P., Poulton, C., Wiggins, S., \& Dorward, A. (2007). The future of small farms for poverty reduction and growth. Retrieved from http://www.ifpri.org/sites/default/files/publications/vp42.pdf

Jayne, T. S., Yamano, T., Weber, M., Tschirley, D., Benfica, R, Chapoto, A., \& Zulu, B. (2003). Smallholder income and land distribution in Africa: Implications for poverty reduction strategies. Food Policy, 28, 253-275.

Key, N., \& Roberts, M. (2007a). Commodity payments, farm business survival, and farm size growth (Economic Research Report No. ERR-51).

Key, N., \& Roberts, M. (2007b). Measures of trends in farm size tell differing stories. Amber Waves, 5(5), 36-37.

McConnell, D. J., \& Dillon, J. L. (1997). Farm management for Asia: A systems approach (FAO Farm Systems Management Series 13. FAO, Rome).

McCullough, E., Pingali, P. L., \& Stamoulis, K. G. (2008). The transformation of agri-food systems: Globalization, supply chains and smallholder farmers. London: Earthscan Press.

World Bank. (2008). World Bank development report agriculture for development. Washington, DC: World Bank. 